\title{
Serum Immunoglobulin Levels in Children with Acute Lymphoblastic Leukaemia and Their Mothers and Sibs
}

\author{
R. K. CHANDRA \\ From the Department of Paediatrics, Immunology Division, All India Institute of Medical Sciences, New Delhi, India
}

Chandra, R. K. (1972). Archives of Disease in Childhood, 47, 618. Serum immunoglobulin levels in children with acute lymphoblastic leukaemia and their mothers and sibs. Serum immunoglobulins $G, A$, and $M$ were estimated in 29 children with acute lymphoblastic leukaemia and their first-degree relatives. 6 newborn sibs had high IgM levels in cord blood. IgG and IgM were raised in the mothers' sera and there was a significant decrease in the serum IgG of sibs aged 2 to 10 years. The findings suggest the presence of some antigenic stimulus, possibly a virus, in the intrauterine life of affected sibships. It is postulated that the immunoglobulin abnormalities may be related pathogenetically to the leukaemic process.

The aetiology of leukaemia is largely unknown. Radiation is the only leukaemogenic agent which is firmly established on the basis of studies on the survivors of the atomic bomb explosions in Japan (Bizzozero, Johnson, and Ciocco, 1966), and from data on therapeutic irradiation (Watkins, Fairley, and Scott, 1967). There is considerable evidence implicating viruses in the causation of malignancies including leukaemia in animals (Burdette, 1966). In man, such a presumption is made on the basis of indirect incriminating data such as time-space clusters of acute leukaemia patients (Knox, 1971), the geographical distribution of Burkitt's lymphoma (Burkitt and Wright, 1966), and the successful development of lymphoma in monkeys inoculated with biopsy material from a patient with Burkitt's lymphoma (Epstein, Woodall, and Thomson, 1964). The aetiological significance of virus-like particles in the bone-marrow of some patients and the isolation of mycoplasma in a few is debatable. At best, the evidence is controversial. For instance, the application of two different analytical approaches to patient clusters yielded diametrically opposite results (Knox, 1964; David and Barton, 1966).

Several reports suggest a pathogenetic significance for the recorded association between immunodeficiency, autoimmunity, and lymphoproliferative disorders (Page, Hansen, and Good, 1963;

Received 20 January 1972.
Fudenberg, 1966; Fraumeni and Miller, 1967). Sutton, Bishun, and Soothill (1969) studied firstdegree relatives of children with acute lymphoblastic leukaemia, and found reduced serum IgA levels in sibs and raised serum IgM in the mothers. A significant observation in their study was a great rise in IgM and IgA in the cord blood of a newborn sib.

We record our observations on serum immunoglobulin levels in 29 children with acute leukaemia, 48 of their sibs including 6 neonates, their mothers, and matched controls.

\section{Patients and Methods}

Twenty-nine children, aged 2 to 10 years, were diagnosed to have acute lymphoblastic leukaemia, on the basis of morphological characteristics of peripheral blood smear and bone-marrow aspirate. Also studied were their 6 neonate sibs, 42 sibs aged 2 to 10 years, and their 29 mothers. Healthy controls from the same community were matched for age and sex in the case of the patients and their sibs 2 to 10 years old, and for age and parity for the mothers. Control data for immunoglobulin levels in the cord blood were derived from examination of samples from 130 consecutive deliveries in a local maternity hospital.

Serum samples were collected before initiation of therapy. They were stored at $-4^{\circ} \mathrm{C}$, and within 4 weeks, serum immunoglobulins were estimated by the single radial diffusion in agar method of Mancini, Carbonara, and Heremans (1965), using specific antisera. 
Control samples and WHO Reference Standard were also run on the same plate to avoid methodological errors through interplate variations.

In the case of the 6 neonate sibs, a second serum sample was obtained 1 to 28 weeks after birth.

Statistical analysis of the results was done to find out if the mean of differences in serum immunoglobulin values of each experimental-control pair differed significantly from zero on the Student's ' $t$ ' test.

\section{Results}

All 6 newborn sibs showed high levels of IgM in the cord blood, which persisted for at least 1 to 28 weeks, when a second estimation was made (Table I). There was a significant increase in

\section{TABLE I}

Serum Immunoglobulin Levels in Cord Blood of 6 Sibs of Children with Acute Leukaemia, Repeat Samples, and 130 Controls

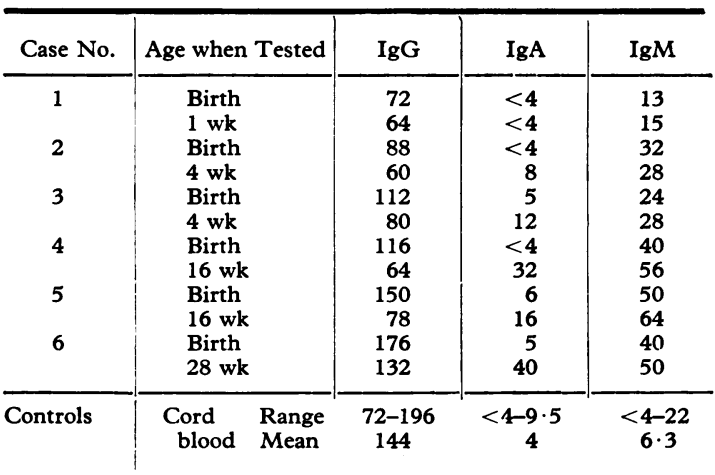

Note: Values are expressed as percentage of WHO Reference Standard.

serum values of $\operatorname{IgG}$ and $\operatorname{IgM}$ in the mothers of the patients (Table II), and a significant decrease in the serum IgG of the sibs aged 2 to 10 years (Table III)

\section{TABLE II}

Serum Immunoglobulin Levels in Mothers of Children with Acute Leukaemia and in Age-Parity Matched Healthy Controls

\begin{tabular}{c|c|c|c|c}
\hline Group & No. & IgG & IgA & IgM \\
\hline $\begin{array}{c}\text { Mothers of children } \\
\text { with leukaemia }\end{array}$ & 29 & $210 \pm 49$ & $136 \pm 32$ & $271 \pm 54$ \\
$\begin{array}{l}\text { Control mothers } \\
29\end{array}$ & $141 \pm 43$ & $127 \pm 29$ & $196 \pm 47$ \\
\hline $\mathrm{P}$ & $<0.01$ & $>0.6$ & $<0.01$ \\
\hline
\end{tabular}

Note: Values are expressed as geometric means and SDs calculated as percentages of WHO Reference Standard.

\section{TABLE III}

Serum Immunoglobulins in Sibs Aged 2 to 10 of Children with Acute Leukaemia and Age-Sex Matched Healthy Controls

\begin{tabular}{l|c|c|c|c}
\hline \multicolumn{1}{c|}{ Group } & No. & IgG & IgA & IgM \\
\hline $\begin{array}{l}\text { Sibs of children } \\
\text { with leukaemia }\end{array}$ & 42 & $89 \pm 29$ & $112 \pm 32$ & $148 \pm 37$ \\
Control children & 42 & $145 \pm 42$ & $124 \pm 40$ & $130 \pm 42$ \\
\hline $\mathbf{P}$ & & $<0.01$ & $>0.3$ & $>0.2$ \\
\hline
\end{tabular}

Note: Values are expressed as geometric means and SDs calculated as percentages of WHO Reference Standard.

In patients with acute leukaemia, there was a very wide scatter of values of the 3 immunoglobulins, but they differed as a group from the healthy controls in having a significantly lower serum IgG concentration (Table IV).

\section{TABLE IV}

Serum Immunoglobulins in Children with Acute Lymphoblastic Leukaemia and Age-Sex Matched Healthy Controls

\begin{tabular}{l|r|r|r|r}
\hline \multicolumn{1}{c|}{ Group } & No. & IgG & IgA & IgM \\
\hline $\begin{array}{l}\text { Children with } \\
\text { leukaemia }\end{array}$ & 29 & $72 \pm 56$ & $85 \pm 34$ & $124 \pm 37$ \\
Control children & 29 & $128 \pm 34$ & $96 \pm 31$ & $132 \pm 26$ \\
\hline$P$ & & $<0.01$ & $>0.06$ & $>0.2$ \\
\hline
\end{tabular}

Note: Values are expressed as geometric means and SDs calculated as percentages of WHO Reference Standard.

\section{Discussion}

If childhood leukaemia is caused or initiated by a virus infection in early life, it may result in other more easily measurable effects. There is a possibility that such an exposure may occur in utero, analogous somewhat to the vertical transmission of leukaemogenic virus in certain highly inbred strains of mice. If this were true for man, it would cause a significant alteration in the serum immunoglobulins of the patients, and possibly of the mothers and sibs, including an accelerated rate of immunological maturation of subsequent fetuses. Intrauterine infections, such as rubella, induce a significant fetal synthesis of IgM which is detectable at birth (Soothill, Hayes, and Dudgeon, 1966).

Our observation of raised IgM in the cord blood of all 6 newborn sibs of patients with acute lymphoblastic leukaemia confirms and extends the finding in one such infant by Sutton et al. (1969). This suggests the existence of an antigenic stimulus 
during the fetal life of these neonates. This could well be the leukaemogenic agent(s) whatever its nature may be. Raised levels of IgG and IgM in the mothers would support the presence of a chronic infection in them, perhaps by a virus.

Besides the possible effect of environmental influences, constitutional factors seem to be important in the aetiopathogenesis of acute leukaemia in man (Lancet, 1972). The high frequency of leukaemia in patients with Down's syndrome, Fanconi's anaemia, Bloom's syndrome, and ataxiatelangiectasia would support this belief. Such a susceptibility may well be based on immunodeficiency, inherited or acquired. In sibs other than neonates, we found a significant lowering of serum IgG levels. Sutton et al. (1969) noted IgA deficiency in sibs of acute leukaemia patients studied by them. The immunoglobulin abnormalities may be genetically determined or be the result of an environmental influence acting in early life during the initial phases of development of the immune system. For instance, IgG deficiency has been reported in some infants with congenital rubella (Soothill et al., 1966). In mice, a similar phenomenon of selective depression of IgGforming plasma cells may be seen after strong antigenic stimulus soon after birth (Chandra and Soothill, 1971). The familial immunoglobulin abnormalities might themselves predispose to acute leukaemia. For instance, the proliferation of malignant cells occurring through random mutation or as a result of a leukaemogenic agent, may be facilitated by a breakdown in the 'surveillance' mechanism. It is possible that the familial occurrence of a leukaemogenic agent may result in both leukaemia and immunodeficiency. The consistent association of malignancies of the lymphoreticular system with immunity deficiency and autoimmune disorders lends support to the existence of such aetiopathogenetic links.

I am grateful to my colleagues for access to their patients and to Professor O. P. Ghai for permission to publish this paper. Professor John Soothill gave useful suggestions in the revision of the manuscript. The WHO Reference Standard for Immunoglobulins was kindly supplied by Dr. David Rowe.

\section{REFERENCES}

Bizzozero, O. J., Jr., Johnson, K. G., and Ciocco, A. (1966) Radiation-related leukemia in Hiroshima and Nagasaki, 1946-64. I. Distribution, incidence and appearance time. New England fournal of Medicine, 274, 1095.

Burdette, W. J. (1966). Viruses Inducing Cancer. University of Utah Press, Salt Lake City.

Burkitt, D., and Wright, D. (1966). Geographical and tribal distribution of the African lymphoma in Uganda. British Medical fournal, 1, 569.

Chandra, R. K., and Soothill, J. F. (1971). Suppression of developed spleen haemolytic plaque formation by neonatal antigen stimulus in mice. Immunology, 20, 175.

David, F. N., and Barton, D. E. (1966). Two space-time interaction tests for epidemicity. British fournal of Preventive and Social Medicine, 20, 44.

Epstein, M. A., Woodall, J. P., and Thomson, A. D. (1964). Lymphoblastic lymphoma in bone-marrow of African green monkeys (Cereopithecus aethiops) inoculated with biopsy material from a child with Burkitt's lymphoma. Lancet, 2, 228.

Fraumeni, J. F., Jr., and Miller, R. W. (1967). Epidemiology of human leukemia; recent observations. Fournal of the National Cancer Institute, 38, 593.

Fudenberg, H. H. (1966). Immunologic deficiency, autoimmune disease, and lymphoma: observations, implications, and speculations. Arthritis and Rheumatism, 9, 464.

Knox, E. G. (1964). Epidemiology of childhood leukaemia in Northumberland and Durham. British Fournal of Preventive and Social Medicine, 18, 17.

Knox, E. G. (1971). Epidemics of rare diseases. British Medical Bulletin, 27, 43.

Lancet (1972). Editorial. Epidemiology of leukaemia, 1, 82.

Mancini, G., Carbonara, A. O., and Heremans, J. F. (1965). Immunochemical quantitation of antigens by single radial immunodiffusion. Immunochemistry, 2, 235.

Page, A. R., Hansen, A. E., and Good, R. A. (1963). Occurrence of leukemia and lymphoma in patients with agammaglobulinemia. Blood, 21, 197.

Soothill, J. F., Hayes, K., and Dudgeon, J. A. (1966). The immunoglobulins in congenital rubella. Lancet, 1, 1385.

Sutton, R. N. P., Bishun, N. P., and Soothill, J. F. (1969). Immunological and chromosomal studies in first-degree relatives of children with acute lymphoblastic leukaemia. British fournal of Haematology, 17, 113.

Watkins, P. J., Fairley, G. H., and Scott, R. B. (1967). Treatment of polytythaemia vera. British Medical fournal, 2, 664 .

Correspondence to Dr. R. K. Chandra, Department of Paediatrics, All India Institute of Medical Sciences, New Delhi 16, India. 